Article

\title{
Rethinking Consumerism from the Perspective of Religion
}

\author{
Mikko Kurenlahti ${ }^{1, *}$ and Arto O. Salonen ${ }^{2}$ \\ 1 Faculty of Theology/Study of Religions, University of Helsinki, 00014 Helsinki, Finland \\ 2 Faculty of Social Sciences and Business Studies, University of Eastern Finland, 70211 Kuopio, Finland; \\ arto.salonen@uef.fi \\ * Correspondence: mikko.kurenlahti@helsinki.fi; Tel.: +358-29-412-3595
}

Received: 12 May 2018; Accepted: 12 July 2018; Published: 13 July 2018

\begin{abstract}
Due to the global challenges that are posed by the Anthropocene and the academic focus on the fragmented state of modernity, we extend an invitation for shared dialogue on the all-pervading nature of consumerism as the seemingly problematic ethos of Western consumer culture. To this end, we outline a way to approach consumerism as an implicit religion, theorized as having adopted functionalities related to explicitly faith-based traditions within secular settings. We suggest that a similar kind of holistic and multidimensional approach might be of great benefit in the implementation of sustainability, as this would allow, e.g., (i) a more holistic analysis of the all-pervading nature of consumerism; (ii) acknowledgement of the functional diversity of the phenomenon; (iii) recognition of the shallowness of the critique of consumerism as a way of life; and, (iv) shared dialogue across a spectrum of academic perspectives under a unified model. This approach problematizes standard interpretations of consumerism as being about the promotion of the individual against the collective and as leading to a general sense of purposelessness. The perspective of religion reveals how patterns of consumption become illuminated with meaning and connected to a shared way for individuals to articulate a sense of purpose in contemporary contexts.
\end{abstract}

Keywords: religion; secular; consumerism; consumer culture; consumption; sustainability education; sustainable development; Anthropocene; implicit religion; social change; digitalization

\section{Introduction}

In this article, we adopt the perspective of religion to rethink consumerism as an existential strategy, and discuss the meaning of this point of view in the age of the Anthropocene-the geological epoch defined by the dominant impact of humans on the global environment [1-3]. Our aim is to integrate perspectives of the study of religions with the field of sustainability studies to offer new approaches to the pursuit of sustainable lifestyles under the generally secular orientation of Western consumer culture. We hypothesize that consumerism is not so much about individual materialistic tendencies, but more about the formation of transcendent meanings that are inherently social and existentially significant by nature. As a result, we approach consumerism as an implicit religion - a concept developed by Edward Bailey [4] — in order to offer a more holistic theoretical framework of the all-pervading meaning of this phenomenon under contemporary-and increasingly digitalized—conditions of the West.

The subject of consumerism as an implicit religion is rarely approached through sustainability studies. Implicit religion refers to an analytical perspective that allows for the adoption of the point of view of religion to analyze seemingly nonreligious or otherwise secular phenomena, meaning systems or commitments [4] (pp. 7-9). The term bears close resemblance to such concepts as civil [5] and invisible religion [6]. However, we do not claim that consumerism is a religion, but that the perspective 
of religion might offer invaluable insights into the nature of the phenomenon and into the promotion of sustainability in secular settings. It should also be noted that it falls outside of the stated scope of this article to analyze explicitly religious perspectives on consumerism-observing the phenomenon from the outside in. Instead, the perspective of religion is adopted in order to understand consumerism from the inside out-a methodological approach that is underused in existing research on the subject.

We begin by offering a general overview of research concerning the relationship between religion and consumption, discussing the nature and potential problems with the existing body of scholarship and highlighting the importance of the emergent more holistic model of consumerism. We then introduce a way to understand the dynamics between culture, religion, and consumption in contemporary settings and offer contextualized definitions for Western consumer culture as a way of life, consumerism as an ethos for this cultural context, and religion as a way of constructing life-meaning, while also considering the general role and significance of consumption in the Anthropocene.

After this, we proceed to outline a preliminary theoretical macro-cultural framework, which is built especially around the anthropological theories of Clifford Geertz (1926-2006), to make sense of how consumerism exists within the fabric of everyday life in the West, with the aim of using this approach to understand consumerism from the perspective of religion. We will also argue that this approach demands no engagement with the domain of the supernatural-a realm that is usually taken to be foreign or otherwise problematic to either the public sphere of everyday life in modern societies or more specifically to sustainability studies. The theoretical framework offered aims to broaden the current scientific consensus, which is evident especially in the academic fields of cultural studies and the sociology of culture [7] (p. 1), over the role of consumerism as a symbolic language.

Against this framework, we will apply functional theories of religion to the study of consumerism, which seems to have adopted functionalities typically related to explicitly faith-based traditions, as an ideological construct. Our goal is to demonstrate how this approach can be used to combine different sides of often fragmented, consumerism-related research under a unified theoretical model to enable a shared dialogue that is focused on overcoming the global challenges posed by the Anthropocene. To this end, the literature reviewed represents several different fields of research, such as consumer culture theory, consumer psychology, anthropology, and theology, as well as marketing, social, cultural, media and communication, and sustainability studies, in dialogue with the study of religions. In this context, the phenomenon of religion is approached primarily from a sociological perspective. We argue that a more holistic model of consumerism, such as the one that is outlined in this article, is not only useful but of pressing value in the effort to mobilize social changes towards sustainability-changes that can be driven by transformative learning [8].

\section{The Relationship between Religion and Consumption in Previous Research}

Most academic fields engaged in sustainability research seem to see themselves as part of the modernization and secularization projects usually interpreted as strongly opposite to the realm of religion. For example, Environmental Studies Professor Susan Power Bratton [9] (p. 1) argues, "universities reward scholars for innovation, which promotes critique of dominant or mainstream religious forms. Both environmental advocates and academics propose new eco-friendly alternatives-often without any in-depth conversations with adherents of the 'bad' or 'old' religion". This implies that "religion" is antithetical to the "modern" [10] (pp. 127-128) in the broad field of interdisciplinary sustainability studies. Perhaps theories of secularization [10] (pp. 127-150), albeit inaccurate from a sociological point of view [11,12], have given rise to this problematic perspective. Religion thus represents an underdeveloped and under-researched area in this research context-especially in connection with the analysis of seemingly secular phenomena. Furthermore, the majority of sustainability-related research that is engaged with the domain of religion has focused on the analysis of various explicitly religious traditions, resources, and communities [9,13-15].

The same narrow focus can be found in research concerning the relationship between religion and consumption (or economics in general) in the academic field of the study of religions, as showcased 
by the typology that is offered by François Gauthier et al. [16] (pp. 267-269). According to their research, major themes of interest have been: (i) the seemingly negative impact of consumer culture on religious traditions [16] (p. 267); (ii) how consumer capitalism has stimulated changes in the religious landscape [16] (p. 267); (iii) the emergence of "prosperity religion" [16] (p. 268); and, (iv) the blurred boundaries between state and religion in the context of welfare [16] (p. 269); all four of these themes approach the meaning of consumer culture from the perspective of explicitly religious traditions or communities. It should also be further noted that research focused on the relationship between religion and consumption is generally scarce [17] (p. 12) [18] (p. 316). Gauthier et al. sum up the situation by stating, "consumption remains relatively understated and under-theorized in the social sciences-especially in relation to religion" [19] (p. 2).

Thus, the already insufficient academic interest has primarily served to highlight the reactionary attitude of religious traditions to the existential challenges that are posed by the dominant cultural ethos of consumption. As a result, there are limited possibilities for understanding how the cultural backdrop of consumerism itself seems to have assimilated functionalities typically related to faith-based traditions. Studies engaged in such questions are extremely marginal [19-23]. Gordon Lynch, reflecting on the ideas proposed by Thomas Luckmann [6], laments the narrowness in the approach of academic research on the importance of religion in contemporary societies, stating that "[1]imiting the study of religion [ ... ] to issues related to institutionalized religions could [ ... ] blind us to some of the most pressing questions about stories, values and meanings that shape many people's lives today" [24] (p. 130). In the Anthropocene, consumerism certainly constitutes one such meaning-making force.

In the academic field of theology, research that is related to the relationship between religion and consumption seems to have emphasized the importance of religious faith. Faith-based traditions (typically Christianity) are often presented as counter-cultures, offering superior resources for meaning construction than consumerism [17] (p. 5) [19] (p. 2) [25,26]. For an overview, see [18]. Matthias Zick Varul has characterized this religiously inspired criticism of consumerism as a continuation of criticism against the adoration of the Golden Calf [21] (p. 447). From this point of view, he remarks that Tim Jackson \& Miriam Pepper [20], whose primary interest lies in the exploration of the functional similarities of religion and consumption, end up exposing consumerism as a false theodicy [21] (p. 447). Similarly, Bruce Rittenhouse [25], who does argue that we should understand consumerism as an existential strategy, ends up promoting Christianity as a far superior alternative to this false religion. This approach seems to reproduce the dichotomy of "modern" and "religion" in much the same fashion as happens within the secularization paradigm. Likewise, this line of argumentation seems to rely on, or at least seems to aim at inspiring, religious faith. Although there is a definite need for an open dialogue between various perspectives on the subject, it might prove difficult to engage with the more general sustainability-related discussion from the basis of such explicitly religious arguments in any other role than as a representative of a particular tradition.

If religion has proven to be a difficult subject within sustainability studies, consumption has also long been perceived to be a phenomenon that is too trivial to be taken seriously [16] (pp. 269-270), largely interpreted simply as a by-product of work and production [19] (pp. 1, 5) [27] (p. 2) [28]. This perspective was adopted by such influential figures as Max Weber (1864-1929) [29] and those influenced by his research [19] (p. 5). It is only recently that consumption has started to receive the academic attention it deserves as an independently important cultural ethos that is strongly linked to the definition and pursuit of a meaningful life [30-35].

However, it remains problematic how strongly contemporary consumption-related research seems to emphasize the abstract and heterogeneous nature of consumption, seen to exist in a fragmented framework of overlapping meanings and that can only be studied within a variety of situated settings [27] (p. 34) [30] (p. 376) [36,37] [38] (pp. xix-xx). Such a strong emphasis on the regional and localized aspects of consumption might inhibit the development of a more holistic theory of consumerism as a cultural phenomenon that is linked to a fairly homogeneous way of life. Indeed, "further study on the 
topic is needed" [18] (p. 316) from the perspective of religious studies, especially to develop systemic perspectives on consumerism that aspire to collective transformation [18] (p. 320).

\section{Culture, Religion and Consumption in the Commercialized West}

\subsection{The Western Consumer Culture \& the Ethos of Consumerism}

The political philosopher Michael J. Sandel said, "we drifted from having a market economy to being a market society" [39] (p. 10). Steven Miles goes a step further by stating, from the 1980s onward, "what was emerging was not merely a consumer society, but a consumer culture" [27] (p. 9). In principle, our use of the term "culture" in the context of this article refers simply to a way of life that has generally been taken up by a specific group of people $[40,41]$. From this perspective, the term withholds all of the characteristic features of human coexistence regarded as "natural" by the majority of people living in the context of the community in question [42]. This is also generally the stance occupied by British and American cultural studies and adopted by such fields of research as media anthropology [43] (p. 4).

Therefore, by the phrase "Western consumer culture", we refer to the generally accepted way of life in Western consumer societies of the late 20th and early 21st centuries, in which "involvement with material culture is such that mass consumption infiltrates everyday life not only at the levels of economic processes, social activities and household structures, but also at the level of psychological experience-affecting the construction of identities, the formation of relationships, the framing of events" [44] (p. 24). As used here, the term "consumer society" has a more geographical meaning and it refers to the several locational communities who share this specific cultural bond associated with an elevated importance placed on patterns of consumption. If "consumer culture" is to be understood as more or less synonymous with "consumer lifestyle", then "consumer society" is the kind of society that promotes such a way of life above all other alternatives [45] (pp. 52-53). In this context, consumerism can be characterized in the way that was suggested by Jackson \& Pepper, as "the attempt to internalize through the use and exchange of commodities the maintenance of a world view in which the use and exchange of commodities is the principal mechanism for social progress" [20] (p. 24) [22] (p. 8).

We further highlight the importance of approaching consumerism from a much wider perspective than has usually been taken up in previous research, as a phenomenon not to be reduced to "materialism" or "material values" [46] (p. 36). It is important to recognize, for instance, how the lines between producer, consumer, and product have become increasingly blurred, e.g., in the context of social media or dating apps, such as Tinder; both are prime examples of the commodification of self $[35,47]$ in the ever-digitalizing world of today. Consumerism is not simply about "material culture", but is also increasingly about the consumption of the non-material, such as popular culture, media content, data, information capital, experiences, etc. [30] (p. 377). It is also important to recognize to what extent the on-going globalization of consumerism has led to cultural homogenization, as neoliberalism and consumer capitalism are becoming global standards [16] (pp. 272-273) [19] (pp. 1-2) [48] (p. 140), a process that undermines the academic focus on the supposedly fragmented nature of consumption.

The academic understanding that modernity exists in a fragmented state is not unexpected, as the modern reality is characterized by the emergence of a multitude of parallel consumer identities that are stretching across a variety of platforms. At the same time, human religiousness has also been observed to be transformed towards more vernacular forms [12]. In this context of apparent individual independence and self-reliance, one can today identify such phenomena as the marketplace of religion, in which people are hypothesized to have more personal freedom to choose the worldview they affiliate themselves with and to simultaneously exist between a myriad of identities [16] (pp. 127-224) [49]. However, although Western consumer culture manifests itself in a multitude of ways-for example, as a spectrum of so-called consumer tribes [50,51] —all of these sub-categories can be said to ultimately derive from consumerism as a dominant ideology. In any given example, attitudes towards consumption of some form are always elevated to a centralized position in an attempt 
to articulate the meaning of life in a contemporary setting. We suggest that it is precisely this emphasis on life-meaning that opens the way to approach the ideological phenomenon of consumerism from the more holistic perspective of religion.

\subsection{Approaching Religion as the Construction of Life-Meaning}

To approach consumerism from the perspective of religion, a term defined by Gauthier et al. as "diffused, fragmented, deregulated, amorphous, and so on" [16] (p. 262), necessitates that the researcher take up a theoretical perspective on a phenomenon that can be-and is-defined in a multitude of different ways [22] (pp. 2-13). In the academic field of the study of religions, the discussion of the definition of the term has been painfully long [24,52] [53] (pp. 27-33), for some to the point of ridiculousness [54] (p. 107), and it is precisely for this reason that we will not attempt to engage with this topic more than needed. However, we wish to underline the fact that, in the context of this article, the term "religion" does not presuppose whether one should be for or against religion [22] (p. 2). Rather, we aim to offer a generally inclusive, theoretically useful, and functionally relevant model of this phenomenon, which is adoptable in sustainability research and education, despite the various opinions towards religion adhered to by the people involved.

Over the course of the arguments that follow, we approach religion in the vein of such scholars of the sociology of religion as Émile Durkheim (1858-1917), Max Weber, Peter L. Berger (1929-2017), and Clifford Geertz-as a seemingly inescapable functional category aiming generally at the creation of life-meaning [55]. This perspective sidesteps what is usually the most problematic aspect of religion under the secularized conditions of Western consumer culture: the supernatural. This should not be understood as an attempt to deny the validation of explicitly religious ideas or beliefs, but as an effort to find functional use-value for the insights that are offered by the constructed category of "religion" in a field of research usually foreign to such arguments. By approaching religion as the creation of life-meaning, we arrive at the same conclusion as Hugh Rock: "Contemporary society is [ ... ] a religious society. What convention refers to as 'secular' is a religious domain" [55] (p. 445). In our argumentation this statement is taken further to concern a specific cultural macro-level.

This statement, which is developed further in Section 4, is not meant as a provocation but is presented as a useful way to approach the often-problematic nature of the religious/secular divide [4] (pp. 4-7). There exists fluidity between the categories that leads to mutual contingency. The differences between the two are not so much to be found out there in the world, but rather dependent on the way that the terms are constructed and defined in different times and places, and by different people [56] (p. 58). This is precisely what is meant by referring to religion as a "constructed category". For this reason, our definition of religion-in this context explicitly a creation of academic study-needs to be understood as an attempt to consciously approach the domain of religion from an angle perceived as being compatible with the general secularism of the sustainability movement. In order for the term "religion" to function as an analytical perspective in this field of research, an ontologically non-vocational approach to the category needs to be defined.

\subsection{Consumption in the Anthropocene}

To apply the perspective of religion to the study of consumerism in the Anthropocene, we first need to hypothesize what the overarching meaning of this phenomenon is and the problematic outcomes that follow. A starting point can be found in the theoretical consensus across several fields of research-including sociology of culture [45,57], consumer research [58,59], social psychology [60], and anthropology [61-63] - that consumerism is a symbolic language [4] (p. 1) [20] (p. 24) [64]. As patterns of consumption have, in many cases, transcended the actual basic needs of people that are living in the context of Western consumer culture, commodities, and other consumer goods and services have become a shared way for people to "communicate continually with each other, not just about raw stuff, but about what really matters to us: family, friendship, a sense of belonging, community, identity, social status, meaning and purpose in life" [20] (p. 24). Most social or cultural theories of 
consumption agree that what people actually consume are meanings, social signs, dreams, fantasies, etc. [20] (p. 24) [21] [27] (pp. 3, 26).

Despite this academic consensus, the current emphasis on the fragmented state of modernity seems to have led scholars of different fields to ponder questions such as these that were posed by historian Frank Trentmann: "should we study objects, signs or experiences, focus on the drive to emulate others or to differentiate oneself, analyse acquisitive mentalities or ironic performances, condemn resulting conformity or celebrate subversion?" [30] (p. 373). Indeed, most of the influential attempts to posit a more unified social theory of this phenomenon-such as The Consumer Society, by Jean Baudrillard [57] — are usually decades-old, antedating such global revolutions in the context of contemporary everyday life as the digitalization project and the emergence of social media [43]. Already in the late 90's, Steven Miles observed, "current conceptions of consumption are insufficient, particularly in terms of what they can say about consumerism as a way of life" [27] (p. 28). Also, the seminal work done on the subject by the insightful social thinker Zygmunt Bauman differs from our approach, as Bauman strongly emphasizes the inherent loneliness of the consuming act. According to him, "the activity of consumption is a natural enemy of all coordination and integration" [28] (p. 31).

All of this can be seen to pose an issue for the development of sustainability education, as the root of the problem does not seem to be consumption per se, but rather the way that it currently operates in the context of a shared profit-led worldview $[65,66]$. That is to say, the problem is not with the act of consumption itself, but with the socially constructed motives behind the behavior and the culturally shared ideological drive that sustains the status quo. Consumption as an activity, as something we do as living members of Earth, is an ontological fact that needs to happen in one form or another, if our existence is to continue. Sustainable development itself is based on the fact that all known life-forms depend on the world's resources to survive and flourish; all beings are interdependent. However, even the term "consumerism" suggests that there is something more happening than mere "consumption" [27] (p. 4).

The more problematic aspects of the current status quo seem to have much to do with the economized way "the good life" is currently sought after in the context of market capitalism [67] (pp. 5-6) [68,69]. It is this inextricable link between consumerism and meaningfulness that establishes this cultural force as an existential challenge in the context of learning for sustainability. Sure enough, the eco-social approach to education has been explicitly defined as an attempt to criticize and revolutionize the current economized paradigm of the pursuit of the good life [65] [67] (pp. 5-6). This critique contains many similarities with the ways that religious traditions have interpreted consumerism as constituting a direct existential threat [18] (pp. 317-318).

The unsustainable way of life that follows is materialized in the fact that Earth Overshoot Day [70], the day when humanity has consumed all of the annual natural resources that the planet is capable of regenerating, marches steadily earlier every year. The most often-discussed results of this ecological overspending are climate change and the dramatic extinction event of species, commonly referred to as the sixth extinction. These changes in turn alter the social environment of people, leading to such phenomena as civil unrest, migration, poverty, social injustice, discrimination, famine, water scarcity, health issues, and human rights violations. Consumerism as an ideological construct promoting the Western consumption-saturated way of life seems to point the world on a collision course with the realities of a finite planet [18] (p. 322) [69]. We are facing not only an ecological, economic, or social crisis, but, as economist Manfred Max-Neef has stated, "a crisis of humanity" with colossal repercussions [69] (p. 201). Instead of one crisis after another, we are now facing a multitude of simultaneous crises under the unified category of "the Anthropocene". This realization of the problematic nature of the steadily globalizing status quo of Western consumer culture further underlines the need for a more holistic model of consumerism, to be used as a reference point for the implementation of sustainability education. 


\section{A Macro-Cultural Framework of Consumerism as an Implicit Religion}

We begin outlining the theoretical framework for the more holistic model of consumerism as an implicit religion on the basis of the academic consensus that this phenomenon should be understood as a symbolic language. Following the approach to religion that is outlined above, we turn our attention to the established canon of classic scholars who both approach the phenomenon of religion from a sociological perspective and understand religion as striving for the creation of life-meaning - a position that is similar to our perspective on the subject. According to Hugh Rock, this established canon of academics includes especially Max Weber, Clifford Geertz, and Peter L. Berger [55] (p. 435). We would add to this list also the works of Émile Durkheim as well as those of Jacques Waardenburg (1930-2015). As increasing one's own sense of meaningfulness seems to be one of the primary objectives of sustainability education in its critique of consumerism [71], consumerism, religion, and sustainability education all seem to share the same goal: to provide meaning in life.

In this article, we focus on the cultural theory of Clifford Geertz and his accompanying theory of religion, both of which are semiotic in nature. Geertz classically defines culture as "a system of inherited conceptions expressed in symbolic forms by means of which men communicate, perpetuate, and develop their knowledge about and attitudes toward life" [72] (p. 89). "Culture" can be seen as containing both the internalized worldview and the ethos of a particular group of people [73] (p. 16). The same holds true of Geertz's theory of religion, which he defines as a cultural "system of symbols which acts to establish powerful, pervasive and long-lasting moods and motivations in men by formulating conceptions of a general order of existence and clothing these conceptions with such an aura of factuality that the moods and motivations seem uniquely realistic" [72] (p. 90).

Rock observes, "Geertz stressed the fact that religion [ ... ] is a response to the problem of meaning" [55] (p. 435). To take this statement further, we interpret that at the heart of Geertz's theories is the claim that symbolic communication acts as the glue that holds a community together and aims to saturate life with purpose [74] (p. 1-31) [75-77]. Berger's "world construction" [42] is likewise couched on the theme of life-meaning [55] (p. 435). In "The Sacred Canopy", Berger argues that human societies are wont to produce an illusion of a stable world order, which is interpreted as "natural" and inevitable by the people trying to achieve stability in the constantly shifting reality of their lives [42]. Nowadays, scholars, especially of media and communication studies, have championed the role of media in contemporary formulations of this kind of community-building symbolic communication [43], an outcome of the shared consumption of highly commercialized media content of various forms. This all seems to ultimately result in the formation of the mythical center of Western consumer culture that currently revolves around heterogeneous patterns of consumption.

In light of this theoretical framework, understanding consumption as "a symbolic language" can carry heavy existential connotations. It should be noted that the approach to religion that is suggested by Geertz can also be adapted to the usually scientific worldview of sustainability studies, as it does not center around supernatural entities but around the idea that "the placement of life within a meaningful sense of existence is the domain of religion" [55] (p. 434). This might be interpreted either as suggesting that the universe is indifferent to humanity or vice versa from an explicitly religious perspective. As such, Geertz's theories of culture and religion offer an excellent framework for applying the perspective of religion-as defined in Section 3.2- to the seemingly secularized context of the Western sustainability movement.

The suggested macro-cultural framework that is outlined can be summed up, as follows: people of all societies articulate the meaning of life in a system of inherited concepts (culture) with the aid of a shared system of symbols (religion). In this context, it is implied that communication by means of symbols is the principal mechanism for people to connect with one another (symbolic language). In the context of Western consumer culture-connecting various Western consumer societies under a shared cultural bond - this goal is achieved primarily through the use and exchange of a multitude of consumer goods (consumption). Therefore, in light of both the definition of consumerism that is provided by Jackson \& Pepper and the theoretical consensus of this phenomenon as a symbolic 
language, consumerism - in the form that it manifests within this particular cultural and historical context-can be approached as a shared system of symbols that offers the dominant alphabet for making sense of the world, the self, and the meaning of life. Also, the suggested theoretical framework does not necessitate an explicit need to account for the realm of the supernatural in the process of approaching consumerism from the perspective of religion [53] (p. 29).

This is naturally an oversimplification of a highly nuanced structure, but nonetheless one that seems to be able to function as the ontological foundation for more in-depth research on the overarching meaning of consumerism. This approach might help to shed new light on such questions as why developed countries understand GDP as the standard way to measure societal development or why the glamorous lifestyles of celebrities are taken as manifestations of social progress to the extent that they are perceived as "the icons of the present age, the deities of an entertainment society, in which money, looks, fame and success are the ideals and goals of the dreaming billions who inhabit Planet Earth" [78] (p. viii). In this context, such non-material elements as information, knowledge, or education can also be interpreted as deriving their value from neo-liberal market logics [46] (p. 37) [66] [79] (pp. 205-206) [80] (p. 18).

It is also worth noting the all-pervading nature of consumerism, which includes all forms of consumption. The centralized position of consumption can also be observed, for example, in the context of ethical consumption, in community building through specific consumer tribe membership (e.g., veganism, fan culture, collectors, etc.) and in projects of identity construction in general [46] (p. 37). For example, humanitarian NGOs have been theorized as selling the identity of "a good person" to people by commodifying compassion and philanthropy [81].

The emerging macro-cultural framework outlined above allows us to understand how people have become suspended in commercialized webs of significance that they have spun for themselves. According to Geertz, culture as a semiotic system of shared meaning-making is always inherited, and it would thus be a mistake to confuse the culturally shared patterns of consumption as voluntary acts that people can simply outlearn or deny. It should also be clear that the notion of consumerism far surpasses the definitions of "materialism" and "material values" or individual motivations, such as greed or indifference. Instead, it might be useful to reflect on these words by Kathryn Lofton: "Religion isn't only something you volunteer to join, open-hearted and confessing. It is not only something you inherit, enjoined by your parents. Religion is also the thing into which you become ensnared despite yourself" [22] (p. xi). To join in the mythology of the imagined—and often mediated [82,83] — center of consumer culture is to join in a kind of shared illusion that reifies the experience of everyday life in the West. It is in this sense that Lofton [22] (p. 5) notes as the brilliance of consumer culture that "so much imprisonment is labeled as your deliverance". From this theoretical framework, we begin to sketch out the different functional dimensions of consumerism from the perspective of religion.

\section{Applying Functional Theories of Religion}

\subsection{Substantive vs. Functionalist Approaches}

Although we do not wish to engage in the broader academic discussion on the definition of religion, we suggest that it is crucial to understand the main differences between two of the most influential approaches to defining the abstract nature of this phenomenon: substantive and functionalist [53] (pp. 27-28). A great amount of academic debate over the definition of religion has taken place between these two approaches-both also to be understood more as constructed academic categories than neutral descriptors of objective reality [56] (pp. 57-58). Although our focus will be on the functionalist assumption, a short description of both is needed in order to understand the main differences between these two schools of thought. It should be noted that these approaches are not mutually exclusive. The substantive approach simply tries to define what a religion is, whereas the functionalist approach tries to analyze what it does. Both of the approaches can therefore be 
applied simultaneously to the study of consumerism as an implicit religion. Our introduction to this conversation relies heavily on the work of Gordon Lynch [24,53].

Generally, scholars siding with a substantive definition of religion understand this phenomenon, as characterized by specific elements. A simplified example would be to state that religion is about belief in the realm of the supernatural, such as deities-a definition Lynch repudiates on the basis of the existence of such major religions as Theravada Buddhism, which seem to contain no express belief in supernatural forces [24] (p. 127) [53] (p. 27). Other commonly included core elements are people who play specific religious roles (e.g., priests, shamans, gurus, monks), sacred places (e.g., churches, temples), sacred resources (e.g., prayers, chants, scriptures, myths), and religious rituals or traditions [53] (p. 27). To define religion in these terms would naturally also invoke the need to define such abstract terms as "sacred". Also, many of these elements could just as well be used to describe a variety of seemingly secular phenomena, such as fan culture, celebrity media, hockey games, national parades, or environmentalism [53] (p. 27) [84-86].

All in all, it does not seem possible to establish a universally accurate set of "core elements" that would describe the multitude of religious ideas and behaviors humans have created, maintain and continue to create to achieve a sense of purpose in life. What the substantive approach does help demonstrate is the generally narrow perspective westerners have used to understand "religion". The definition of religion that is presented by Geertz and proposed by us as a starting point to approach the realm of religion in the context of consumerism-related sustainability studies does not make the kind of substantial prejudgments about the content of the beliefs, practices, and values of a particular community that often marks substantive definitions of religion. Our approach is more phenomenological than substantive in nature [73] (pp. 45-46).

We propose that the macro-cultural framework that is outlined above constitutes a substantive interpretation (purposefully simplified, abstract, and elastic) of consumerism in so far as we understand it as an implicit religion that exists within the fabric of everyday life and the social reality of people. The overarching significance of this phenomenon is that it offers a response to the problem of meaning by adopting the role of a system of symbols functioning as a world- and community-building symbolic language. This language, with existential significance, centers on the use and exchange of commodities, signifying an externally validated manifestation of social progress and ensuring individual value.

The functionalist approach, suggested here as the next step in the creation of a more holistic model of consumerism, does not propose that religion should or even could be characterized by specific core elements. Instead, it focuses on the functions this category seems to perform in the context of both the individual and the community [53] (p. 28). We suggest engaging with the following three main categories of functions religions can serve, as presented and defined by Gordon Lynch [53] (p. 28):

“(i) a social function: religion provides people with an experience of community and binds people into a social order of shared beliefs and values that provide structure for their everyday lives $[\ldots]$

(ii) an existential/hermeneutical function: religion provides people with a set of resources (e.g., myths, rituals, symbols, beliefs, values, narratives) that may help people to live with a sense of identity, meaning and purpose [ ... ]

(iii) a transcendent function: religion provides a medium through which people are able to experience 'God', the numinous or the transcendent $[\ldots]$ '

Lynch introduces these categories as potential ways to study the religious functions of popular culture, noting that a particular cultural phenomenon does not necessarily have to demonstrate all three categories of function to be considered "religious" [53] (pp. 27, 29); here, the term "religion" is to be understood in a similar way to the concept of implicit religion introduced above. Following the example set by Lynch, we suggest that these three categories offer an excellent starting point for trying to understand how consumerism as a cultural phenomenon has adopted functionalities that are typically found in expressly religious traditions or communities. These categories, although 
representing different kinds of perspectives on the phenomenon of religion, also enable a shared dialogue between different areas of consumerism-related research under a unified model; they allow for the combination of key elements of this phenomenon to be observed from a variety of academic perspectives. For example, the categories can be seen as representing different areas of consumer research, such as consumer culture theory, consumer psychology and hermeneutics, and consumer transcendence, all brought together into a more holistic and multi-dimensional approach to the all-pervading nature of consumerism.

\subsection{The Social Function of Consumerism}

The first category centers on the previously cited classic function of religion-that of constructing a common world. This notion can be traced back to the writings of such scholars as Durkheim [87], along whose lines Kathryn Lofton claims that "socialization is our humanization, and religion is the primary social form by which our socialization takes place", and "religion provides a meaning for life, it provides authority figures [ ... ], it reinforces the morals and social norms held collectively by all within a society" [22] (p. 18). The social function of religion also has many similarities with the social development theory of Vygotsky [88] and Berger's theories of world-construction [42].

From this perspective, consumerism allows for the organization of communities around beliefs, myths, values, etc. (the resources of function ii), derived from this ideological undercurrent. This has been understood in marketing research as a focus around a variety of consumption communities [50,89-92]. As argued above, these communities or consumer tribes are heterogeneous and versatile in form, but all seem to fit under the umbrella term of consumerism due to the common, strong emphasis that is placed on acts of consumption. To offer a concrete example of this type of consumption-related community-building, we can observe how veganism, which forms a specific kind of consumer tribe, is defined on the website of the Vegan Society [93]:

"A philosophy and way of living which seeks to exclude-as far as is possible and practicable-all forms of exploitation of, and cruelty to, animals for food, clothing or any other purpose; and by extension, promotes the development and use of animal-free alternatives for the benefit of humans, animals and the environment. In dietary terms it denotes the practice of dispensing with all products derived wholly or partly from animals." [94] (emphasis added)

This definition relies on people coming together to form a social order derived from shared beliefs and values to fulfill the classic function of religion, as characterized by Peter L. Berger as "constructing a common world within which all of social life receives ultimate meaning binding on everybody" [42] (pp. 133-134). In this context, strong emphasis is placed on the communication of values through acts of consumption by promoting alternative choices to consumption related to animal-based products. Therefore, the underlying meaning of patterns of consumption pursued by the community in question are redefined and recontextualized to formulate a similar kind of general order of existence as that articulated by Geertz. What emerges is veganism as "a way of life", a redefined identity of the consumer. Rethinking one's relationship with acts of consumption functions as an initiation, as it were, into a community of like-minded consumers [46] (p. 37). In this context, it is not consumerism that is challenged-on the contrary, consumption receives a centralized position in the process of binding people together to form an experience of community.

\subsection{The Existential Function of Consumerism}

The second category centers around the resources that consumerism offers for the interpretation and experience of everyday life. Where and how do people learn to interpret the meaning of "the good life", when consumerism prevails as the dominant ideology and a way of life? How do they learn the symbolic meaning of consumption and the rules for engaging with this type of symbolic communication? How is this connected to, for example, their sense of self-worth or ontological security? These are key questions in the context of learning for sustainability, as they address the 
"tools" that are used to create and sustain an individual sense of purpose in life. Whereas the social function of consumerism centers on the sense and idea of community, its existential function centers on the resources offering the individual an externally validated sense of value and meaning. This category offers ways to analyze such statements as addressing media environments as "key places where meanings are negotiated and organised" [82] (p. 6) or popular culture as a "common space of commentary in an increasingly personalized world of consumption" [22] (p. 5). This opens up the possibility to incorporate research that is focused on such elements of contemporary life as the existential role of advertising [95] or perspectives on the nature of life in commercialized media societies [83,96] into a more holistic model of consumerism as an implicit religion with existential significance.

To this end, research shows that one of the primary motives for people to engage with the dating app Tinder is to feel better about themselves, to receive feedback on their physical appearance and interests and generally to receive external validation of their individual self-worth [97] (p. 74). In this process of visual self-commodification, focus is given to self-produced images, which, as Gaby David \& Carolina Cambre have argued, "can be seen as adopting the iconographic conventions of advertising and self-branding" [98] (p. 6). In this context, the person himself or herself seems to fall under the spell of market logics, becoming not only a consumer of the images that are offered by other users, but also a producer of their own image and a product as that image. These consumers become themselves symbols of consumerism, interpreting the meaning of their existence from the point of view of their individual saleability among other competing products. Tinder thus serves as one contemporary common space for the construction, negotiation, and organization of existential resources according to the rules of market logics.

A similar kind of blurring between the lines of consumer, producer, and product can be observed in Outi Lundahl's doctoral thesis on marketing [99]. In her study, Lundahl scrutinizes the role superstar Beyoncé, a product of highly commercialized celebrity media [82] (pp. 10, 28), played as a media-enshrined privileged consumer in turning veganism into a fashionable and trendy consumption choice for the public. In this process, the consumption of vegan products, joining the vegan community and constructing a sense of self as a consumer of vegan goods was transformed from a focus on a moral issue to interest in personal wellbeing and health. Beyoncé herself, or at least the public performance of "the good life" that she embodies as a product of the entertainment industry, can be seen as an existential resource "that may help people to live with a sense of identity, meaning and purpose" [53] (p. 28). In a similar fashion, psychologist Charlotte De Backer et al. have studied how young people turn to the domains of popular culture and celebrities for role models in their construction of life strategies [53] (p. 55) [100]. The results show how vulnerable teenagers are to the social impact of popular and celebrity cultures. These examples challenge the shallowness or meaninglessness that popular culture is often accused of [22] (p. 164). From the perspective of the study of religion, these existential resources should rather be approached as a form of modern mythology [61] of high importance to the imagined community [101] of Western consumer culture.

The existential function of consumerism revolves around resources that influence the construction of "the good life", leading to the shared performance of the mythical center of the community. To include this category in the model of consumerism that is proposed herein offers versatile ways to understand how consumption becomes infused with the pursuit and definition of a good and fulfilled life in the context of consumerism as an existential strategy. It should also become evident how easily social and existential functions overlap and are connected to one another. To simply focus on one or another function can produce a limited perspective on the all-pervading nature of consumerism. As this existential category focuses on questions of identity, meaning and purpose, it also has clear connections to such areas of consumer research as, e.g., consumer psychology [102-104]. The significance of this functional category of consumerism is important to recognize, as all attempts to stir collective transformation in everyday life in the West must, in one way or another, contend with 
the currently dominant existential resources that promote the centricity of consumption for achieving a sense of purpose in life.

\subsection{The Transcendent Function of Consumerism}

The transcendent function of consumerism might well be the most important of the three approaches introduced in this article for the study of consumerism as an implicit religion in secular settings. As has been shown above, consumerism in the cultural context of the West seems to have little to do with objects of consumption per se and more to do with the symbolic value that they possess [46] (p. 36). For example, Joerg Rieger observes that the "desire promoted by advertising is not the simple desire for the product; it is for something more transcendent to which the product points, like the hope for happiness and a better life" [46] (p. 36). That is to say, the underlying meaning of the consumption of consumer goods as a method of participating in the kind of symbolic communication that is outlined above goes beyond the physical world of things and material objects. This transcendent function can be imagined as representing the ultimate promises or hopes that drive people to articulate the meaning of life in a "system of shared understandings that keep us working, consuming, and investing in the economy, maintaining it so that it maintains us" [105] (pp. 402-403).

We take a cue from the thinking of Rieger and approach the realm of transcendence as the domain to which the two previous functions point. Gordon Lynch, for example, defines transcendence from the perspective of religion as "an absolute reference point for our existence" [53] (p. 94). From this perspective, the transcendent function of consumerism is the ultimate purpose or concern in life. In explicitly religious contexts, this realm is the dwelling place of such concepts as the sacred, the Absolute, the divine, or the numinous. Such transcendence, in turn, manifests itself in a multitude of ways in the context of consumerism - as it also does within explicitly faith-based traditions-but always in relation to the existential significance of consumption. For instance, the existential resources introduced above represent different means of achieving (or at least to trying to achieve) a glimpse at this absolute meaning of life. Instead of shared prayers, chants, or holy texts, consumers have learned to depend on the consumption of, e.g., media content, which "plays a growing role in shaping people's personal identities and understanding of the wider world" [53] (p. 55).

As stated earlier, consumerism in general has much to do with the act of dreaming and the realm of the imagination. Consumerism feeds on the realization that, when all of the qualitative barriers of traditional society are torn down (for example, the assumption that such traits as lineage, heritage, social background, or gender should automatically determine one's available options in life), all imaginable possibilities are suddenly up for grabs, given the right resources [21] (p. 453). Zick Varul observes that, in this setting of seemingly infinite possibilities, identity construction can be interpreted as becoming a matter of choice [21] (p. 452). What follows are beliefs in the transcendent nature of self-realization and self-fulfillment, such as the following: "No matter what your starting point, you are capable of creating the life you want NOW" [106] (back cover). There is at least one obvious positive aspect to this social evolution: patterns of belief such as these also lead to the emergence of beliefs and actions such as struggles for democracy, social, ecological and economic justice, human rights, and, e.g., gender equality. The equal right to the pursuit of a meaningful existence is also the undercurrent of both humanism and post-humanism.

However, this trajectory of thought also emphasizes the significance of gaining access to and consuming the resources that permit the social progress of an individual in the eyes of others. This is how people can become entrapped in a system of symbolic communication that revolves around patterns of consumption. Zygmunt Bauman [107] (p. 7) has argued that this might also lead to severe individualization, as "the burden of pattern-weaving and the responsibility for failure [falls] primarily on the individual's shoulders" [108] (p. 73). If everyone is seen as personally responsible for their role in life, for example, poverty can become interpreted as a matter of personal failure, leading to immense mental detriment and the loss in one's social status. Consumerism can therefore be interpreted to carry heavy psychological and social burdens and most certainly affect self-actualization amidst the 
poorer sections of both Western societies and other regions of the planet. At the same time, to condemn consumerism as simply leading to cultural hallowing and shallowing might prevent the recognition of the inherently meaningful and social nature of consumption-multiple discourses seem to exist side by side, each leading to various outcomes. To focus one-sidedly on the negative could blind us to the real questions at hand: Why do people keep participating in such an obviously flawed system? What is the underlying meaning of engaging with acts of consumption? How can the motives of consumerism be either redirected or harnessed to promote sustainability?

The transcendent function of consumerism helps us to understand how a general sense of meaning in life becomes entwined with patterns of consumption. To offer one example of such transcendent act of "dreaming" in relation to commodities, in the ongoing non-fiction PBS television series "The Mind of a Chef" (2012-), there is an illuminating scene that depicts the interconnectedness and importance of consumer goods in the realm of the imagination. In season five episode five ("La joie de vivre"), celebrity chef Ludo Lefebvre introduces the viewer to the wondrous world of vintage French consumer goods that are offered by a small shop near his restaurant. Through these consumer goods, both Lefebvre and the viewer are transported to the romanticized streets of France, to reminisce over the childhood of the chef and to recline in Parisian cafés, a dreamscape replete with ethereal floating silverware and other commodities that make this trip to an alternative reality possible. The consumer goods are explicitly showcased to represent dreams and memories, links to a history, community and lifestyle characterized by the title, "La joie de vivre", the joy of living. Various acts of consumption are thus illuminated with meaning. All of this is shown to be obtainable with the right resources, a potential parallel life trajectory to that chosen by chef Lefebvre. Such products point not to their functional use-values or the fulfillment of a particular need, but to a hope for happiness and a promise of attaining "the good life".

This absolute act of dreaming can be interpreted as the engine of consumerism, and is, in itself, a medium through which people are able to experience the transcendent. Once again, there is no apparent need to engage in the domain of the supernatural to gain access to this experience. After all, corporations are known to strive for stimulating flow, peak, and other transcendent customer experiences (TCE), as research has shown this to be one successful means to foster brand loyalty [109]. It is also important to recognize that, from this perspective, consumerism itself is not characterized by a general sense of worthlessness or purposelessness, but, quite the contrary, forcefully ushers consumers towards the pursuit of meaning as dictated by the economic powers that be. If there is a problem in the fabric of the ideology of consumerism, it lies not in the inherent worthlessness of the system itself, but in the apparently unsustainable way meaning is ultimately achieved.

\section{Discussion}

We have argued for the need to engage in more holistic approaches to consumerism as an ideology and not just an empirical descriptor. We extend an invitation for more thorough discussions on the all-pervading nature of this dominant cultural phenomenon and a general shift from shallow anti-consumerist critiques to the recognition of the magnitude of the phenomenon. To this end, we perceive the current academic focus on the fragmented state of modernity and the strong emphasis among consumerism-related research on the study of self-sufficient communities as limiting the scope of research on the phenomenon. As it seems that the physical and social realities of human lives, as well as the non-materialistic worlds of ideas, beliefs, emotions, hopes, dreams, and aspirations are all shaped by the existential strategy of consumerism, it is necessary to establish a common way to engage in dialogue between different fields of sustainability-related research.

Joerg Rieger, for example, argues that, "the appropriate response to the foregoing cannot be to become less materialistic and more spiritual, as if the spiritual world were safer than the material world, and less impacted by the dominant economic interests of capitalism" [46] (p. 37). In addition to situated studies of a variety of consumption patterns, there is a need for the development of more holistic theories of the overarching meaning of consumerism in the context of the everyday 
life-experience of contemporary people that are trying to organize themselves in a world that is illuminated by the triumph of market capitalism. It is important to recognize that, even in cases where consumerism seems to be challenged (for example, by engaging in sustainable consumption, veganism, non-material consumption, or the general favoring of spiritual/cultural/mental capital), people in fact continue to articulate the meaning of life in the framework of consumerism, albeit a revised one. As a result, patterns of consumption maintain a centralized position, potentially allowing for more and more aspects of life to become commodified. Recognition of this pattern is essential in the context of sustainability, as it affects the recognition of the actual goals of education (and of all human development in general) and the means to achieve them.

We have proposed engaging with the categories of religion and the theoretical perspectives offered by the study of religion for sustainability research conducted on the Anthropocene. As it seems that the problems that are posed by this era of global human influence are closely linked to the shared ways "the good life" is pursued, defined and performed under consumer culture in the West, we argue that the under-researched and underdeveloped topic of religion might offer one way to approach consumerism from a more holistic and multidimensional perspective. To this end, we have outlined a preliminary meaning of consumerism as an implicit religion, a seemingly secular cultural phenomenon that seems to have adopted a variety of functionalities that were typically found in explicitly faith-based traditions.

The suggested model builds especially on the theories of Clifford Geertz in order to define a useful analytical approach to religion, which is compatible with the general secularization of the sustainability movement. We suggest that a similar perspective on consumerism might be of great benefit, as it allows: (i) a more holistic analysis of the all-pervading nature of consumerism; (ii) acknowledgement of the functional diversity of the phenomenon; (iii) recognition of the shallowness of the critique of consumerism as a way of life; and, (iv) shared dialogue across a spectrum of academic perspectives under a unified model. We also envision Section 5-focused on applying functional theories of religion-as useful in providing the potential core of an extensive, and more empirical, exploration of the subject. The perspectives offered can be utilized to analyze, for example, the different cultural dimensions of the social behavior of consumerism without succumbing to easy analogies-such as casually referring to shopping malls as places of worship without an exploration to the more precise meaning and implications of such claims.

One of our main goals in this article has been to problematize the standard egocentric interpretation of consumerism as being about the promotion of the individual against the collective [16] (p. 270). Instead, we have argued that consumerism effectively binds the individual to the existential process of shared meaning-making in inescapable ways, and thus connects people together to form ever-expanding consumer societies prone to support the ideals of consumer culture. We also argue strongly against claims that consumerist lifestyles are inherently hollow, worthless, and purposeless. Instead, the perspective of religion reveals a most definite quest for the meaning of life and the construction of individual value-both claims directed outwards into the community in order to be validated externally.

This is why educators should not simply challenge or reject consumerism as a hazardous and unsustainable way of life, but need to find more sustainable ways to engage with this shared act of dreaming-perhaps not so much to challenge but to harness the power of the system people have already internalized. From this perspective, to engage with transformative learning in the context of sustainability education might be understood to aim for the reformation of the currently dominant economized belief system from the inside out. Further studies—both theoretical and empirical—on the subject are needed. Hopefully this article invites more scholarly interest to include the often neglected perspective of religion into the sustainability-related discussion. To quote Kathryn Lofton: "the term religion may still have some critical life, especially as a way to think about social modes of encounter, interaction, and development" [22] (p. 2). 
Author Contributions: M.K. is the main author of this article, which has grown out of his original PhD proposal. He conceived the article and was in charge of performing the analysis for and writing of the original draft. A.O.S. has contributed significantly to the writing and editing of the finalized article. Both authors have read and approved the final manuscript.

Funding: This research received no external funding.

Conflicts of Interest: The authors declare no conflict of interest.

\section{References}

1. Arias-Maldonado, M. The Anthropocenic Turn: Theorizing Sustainability in a Postnatural Age. Sustainability 2016, 8. [CrossRef]

2. Heurtebise, J. Sustainability and Ecological Civilization in the Age of Anthropocene: An Epistemological Analysis of the Psychosocial and "Culturalist" Interpretations of Global Environmental Risks. Sustainability 2017, 9. [CrossRef]

3. Berkes, F. Environmental Governance for the Anthropocene? Social-Ecological Systems, Resilience, and Collaborative Learning. Sustainability 2017, 9. [CrossRef]

4. Bailey, E. Implicit Religious. In Contemporary Society; Kok Pharos: Kampen, The Netherlands, 1997; ISBN 9039005818.

5. Bellah, R.N. Civil Religion in America. Daedalus 1967, 96, 1-21. [CrossRef]

6. Luckmann, T. The Invisible Religion: The Problem of Religion in Modern Society; MacMillan: Basingstoke, UK, 1967; ISBN 978-0025767003.

7. Lodziak, C. The Myth of Consumerism; Pluto Press: London, UK, 2002; ISBN 0-7453-1760-X.

8. Sterling, S. Transformative Learning and Sustainability: Sketching the Conceptual Ground. Learn. Teach. High. Educ. 2011, 5, 17-33.

9. Bratton, S.P. Eco-Dimensionality as a Religious Foundation for Sustainability. Sustainability 2018, 10. [CrossRef]

10. Turner, B.S. Religion and Modern Society; Cambridge University Press: Cambridge, UK, 2011; ISBN 978-0-521-85864-9.

11. Casanova, J. Public Religions in the Modern World; The University of Chicago Press: Chicago, IL, USA, 1994; ISBN 0-226-09535-5.

12. Bowman, M.; Valk, Ü. Vernacular Religion in Everyday Life: Expressions of Belief; Equinox Publishing: Sheffield, UK, 2012; ISBN 9781844658770.

13. Gottlieb, R.S. A Greener Faith: Religious Environmentalism and Our Planet's Future; Oxford University Press: Oxford, UK, 2006; ISBN 9780199850846.

14. Thomas, L. (Ed.) Religion, Consumerism and Sustainability. Paradise Lost? Palgrave MacMillan: New York, NY, USA, 2011; ISBN 9780230576674.

15. Gauthier, F.; Martikainen, T. (Eds.) Religion in Consumer Society. Brands, Consumers and Markets; Ashgate: Farnham, UK, 2013; ISBN 9781409449874.

16. Gauthier, F.; Martikainen, T.; Woodhead, L. Acknowledging a Global Shift: A Primer for Thinking about Religion in Consumer Societies. Implicit Relig. 2013, 16, 261-276. [CrossRef]

17. Thomas, L. Introduction. In Religion, Consumerism and Sustainability. Paradise Lost? Thomas, L., Ed.; Palgrave MacMillan: New York, NY, USA, 2011; pp. 1-16, ISBN 9780230576674.

18. Hartman, L.M. Consumption. In Routledge Handbook of Religion and Ecology; Jenkins, W., Tucker, M.E., Grim, J., Eds.; Routledge: New York, NY, USA, 2017; pp. 316-325, ISBN 9781315764788.

19. Gauthier, F.; Woodhead, L.; Martikainen, T. Introduction: Consumerism as the Ethos of Consumer Society. In Religion in Consumer Society. Brands, Consumers and Markets; Gauthier, F., Martikainen, T., Eds.; Ashgate: Farnham, UK, 2013; pp. 1-26, ISBN 9781409449874.

20. Jackson, T.; Pepper, M. Consumerism as Theodicy: Religious and Secular Meaning Functions in Modern Society. In Religion, Consumerism and Sustainability. Paradise Lost? Thomas, L., Ed.; Palgrave MacMillan: New York, NY, USA, 2011; pp. 17-36, ISBN 9780230576674.

21. Zick Varul, M. Consumerism as Folk Religion: Transcendence, Probation and Dissatisfaction with Capitalism. Stud. Christ. Ethics 2015, 28, 447-460. [CrossRef]

22. Lofton, K. Consuming Religion; The University of Chicago Press: Chicago, IL, USA, 2017; ISBN 9780226482125. 
23. Nelson, R.H. The New Holy Wars: Economic Religion Versus Environmental Religion in Contemporary America; The Pennsylvania State University Press: University Park, PA, USA, 2010; ISBN 978-0271035826.

24. Lynch, G. What is this 'Religion' in the Study of Religion and Popular Culture? In Between Sacred and Profane: Researching Religion and Popular Culture; Lynch, G., Ed.; I.B. Tauris \& Co. Ltd.: London, UK, 2007; pp. 125-142, ISBN 9780857710826.

25. Rittenhouse, B.P. Shopping for Meaningful Lives: The Religious Motive of Consumerism; Cascade Books: Eugene, OR, USA, 2013; ISBN 9781621896043.

26. Moe-Lobeda, C. Resisting Structural Evil: Love as Ecological and Economic Vocation; Fortress Press: Minneapolis, MN, USA, 2013; ISBN 978-1-4514-6267-8.

27. Miles, S. Consumerism. As a Way of Life; Sage: London, UK, 1998; ISBN 0-7619-5215-2.

28. Bauman, Z. Work, Consumerism and the New Poor, 2nd ed.; Open University Press: Maidenhead, UK, 2005; ISBN 033521598 X.

29. Weber, M. The Protestant Ethic and the Spirit of Capitalism, Revised ed.; Oxford University Press: New York, NY, USA, 2010; ISBN 978-0199747252.

30. Trentmann, F. Beyond Consumerism: New Historical Perspectives on Consumption. J. Contemp. Hist. 2004, 39, 373-401. [CrossRef]

31. Featherstone, M. Consumer Culture and Postmodernism, 2nd ed.; Sage: London, UK, 2007; ISBN 978-1412910149.

32. Evans, M.; Moutinho, L.; Van Raaij, W. Applied Consumer Behavior; Addison-Wesley: Harlow, UK, 1996; ISBN 9780201565010.

33. Bartholomew, C.; Moritz, T. (Eds.) Christ and Consumerism: A Critical Analysis of the Spirit the Age; Paternoster Press: Carlisle, UK, 2000; ISBN 978-0853649878.

34. Lyon, D. Jesus in Disneyland: Religion in Postmodern Times; Polity Press: Cambridge, UK, 2000; ISBN 978-0745614892.

35. Pavitt, J. (Ed.) Brand New; Princeton University Press: Princeton, UK, 2000; ISBN 978-0691070612.

36. Arnould, E.J.; Thompson, C.J. Consumer Culture Theory (CCT): Twenty Years of Research. J. Consum. Res. 2005, 31, 868-882. [CrossRef]

37. Arnould, E.J.; Thompson, C. CCT: Ten years gone and beyond. In Consumer Culture Theory; Thyroff, A.E., Murray, J.B., Russell, W.B., Eds.; Emerald Group Publishing Limited: Bingley, UK, 2016; Volume 17, ISBN 978-1-78560-322-8.

38. Fischer, E. A Reflection on the Institutionalization of Consumer Culture Research. In Consumer Culture Theory; Özçağlar-Toulouse, N., Rinallo, D., Belk, R.W., Eds.; Emerald Group Publishing Limited: Bingley, UK, 2017; Volume 18, ISBN 9781786354952.

39. Sandel, M.J. What Money Can't Buy: The Moral Limits of Markets; Farrar, Straus and Giroux: New York, NY, USA, 2012; ISBN 978-1-84-614471-4.

40. Long, E. Introduction: Engaging Sociology and Cultural Studies: Disciplinarity and Social Change. In From Sociology to Cultural Studies; Long, E., Ed.; Blackwell: Malden, MA, USA, 1997; ISBN 978-1577180135.

41. Griswold, W. Cultures and Societies in a Changing World; Pine Forge Press: Thousand Oaks, CA, USA, 2012; ISBN 978-1412990547.

42. Berger, P.L. The Sacred Canopy: Elements of a Sociological Theory of Religion; Doubleday: New York, NY, USA, 1967; ISBN 0-385-07305-4.

43. Sumiala, J. Media and Ritual. Death, Society and Everyday Life; Routledge: London, UK, 2013; ISBN 978-0415684330.

44. Lunt, P.K.; Livingstone, S. Mass Consumption and Personal Identity: Everyday Economic Experience; Open University Press: Buckingham, UK, 1992; ISBN 0-335-09672-7.

45. Bauman, Z. Consuming Life; Polity Press: Cambridge, UK, 2007; ISBN 978-0745640020.

46. Rieger, J. Reshaping Desire at Deeper Levels. In Christianity, Consumerism and the Market; Irrázaval, D., Nadar, S., Ross, S.A., Eds.; SCM Press: London, UK, 2014; pp. 34-43, ISBN 9780334031307.47.

47. Ewen, S. All Consuming Images: The Politics of Style in Contemporary Culture; Basic Books: New York, NY, USA, 1990; ISBN 978-0465001019.

48. Robinson, W.I. Theories of Globalisation. In The Blackwell Companion to Globalization; Ritzer, G., Ed.; John Wiley \& Sons: Milton, Australia, 2008; pp. 125-143, ISBN 9781405132749.

49. Smart, N. Choosing a Faith; Boyars: London, UK, 1995; ISBN 0-7145-2982-6. 
50. Schouten, J.; McAlexander, J.H. Subcultures of Consumption: An Ethnography of the New Bikers. J. Consum. Res. 1995, 22, 43-61. [CrossRef]

51. Maffesoli, M. The Time of the Tribes: The Decline of Individualism in Mass Society; Sage: London, UK, 1996; ISBN 978-0803984745.

52. de Vries, H. Religion: Beyond a Concept; Fordham University Press: New York, NY, USA, 2008; ISBN 978-0823227259.

53. Lynch, G. Understanding Theology and Popular Culture; Blackwell Publishing: Malden, MA, USA, 2005; ISBN 1-4051-1747-8.

54. Bruce, S. Defining Religion: A Practical Response. Int. Rev. Sociol. 2011, 21, 107-120. [CrossRef]

55. Rock, H. Secularisation is an Ecclesiastical Regime of Truth Not a Sociological Event: A Practical Definition of Religion Re-Visited. Int. Rev. Sociol. 2015, 25, 434-455. [CrossRef]

56. Cavanaugh, W.T. The Myth of Religious Violence. Secular Ideology and the Roots of Modern Conflict; Oxford University Press: New York, NY, USA, 2009; ISBN 978-0-19-538504-5.

57. Baudrillard, J. The Consumer Society. Myths and Structures; Sage: London, UK, 1998; ISBN 0-7619-5691-3.

58. Belk, R.W. Possessions and the Extended Self. J. Consum. Res. 1988, 15, 139-168. [CrossRef]

59. Dichter, E. The Handbook of Consumer Motivations: The Psychology of Consumption; MacGraw Hill: New York, NY, USA, 1964; ISBN 978-0070167803.

60. Dittmar, H. The Social Psychology of Material Possessions: To Have is to Be; St Martin's Press: New York, NY, USA, 1992; ISBN 978-0745009568.

61. Barthes, R.; Lavers, A. Mythologies; Paladin Books: London, UK, 1974; ISBN 0-586-08164-X.

62. McCracken, G. Culture and Consumption; Indiana University Press: Bloomington, Indiana, 1990; ISBN 978-0-253-20628-2.

63. Sahlins, M. Culture and Practical Reason; University of Chicago Press: Chicago, IL, USA, 1976; ISBN 0-226-73361-0.

64. Isherwood, M.; Douglas, B. World of Goods: Towards an Anthropology of Consumption; Basic Books: New York, NY, USA, 1979; ISBN 978-0713911633.

65. Åhlberg, M.; Aineslahti, M.; Alppi, A.; Houtsonen, L.; Nuutinen, A.-M.; Salonen, A. Education for Sustainable Development in Finland. In Schooling for Sustainable Development in Europe; Jucker, R., Mathar, R., Eds.; Springer: Cham, Switzerland, 2015; pp. 221-239, ISBN 978-3319095486.

66. Nussbaum, M.C. Not For Profit: Why Democracy Needs the Humanities; Princeton University Press: Princeton, UK, 2010; ISBN 9781400834228.

67. Salonen, A.O.; Bardy, M. Ekososiaalinen sivistys herättää luottamusta tulevaisuuteen. Aikuiskasvatus 2015, 35, 4-15.

68. Taylor, C. Ethics of Authenticity; Harvard University Press: Cambridge, UK, 1991; ISBN 978-0674268630.

69. Max-Neef, M. The World on a Collision Course and the Need for a New Economy. Ambio 2010, 39, $200-210$. [CrossRef] [PubMed]

70. Earth Overshoot Day. Available online: www.overshootday.org (accessed on 29 April 2018).

71. Salonen, A.; Konkka, J. An Ecosocial Approach to Well-Being: A Solution to the Wicked Problems in the Era of Anthropocene. Foro Educ. 2015, 13, 19-34. [CrossRef]

72. Geertz, C. The Interpretation of Cultures: Selected Essays; Basic Books: New York, NY, USA, 1973; ISBN 978-0-465-03425-0.

73. Grassie, W. The New Sciences of Religion: Exploring Spirituality From the Outside In and Bottom Up; Palgrive MacMillan: Basingstoke, UK, 2010; ISBN 9780230114746.

74. Peters, J.D. Speaking into the Air: A History of the Idea of Communication; University of Chicago Press: Chicago, IL, USA, 2000; ISBN 978-0226662770.

75. Carey, J.W. Communication as Culture: Essays on Media and Society, 2nd ed.; Routledge: New York, NY, USA, 2008; ISBN 978-0415989763.

76. Blumer, H. Symbolic Interactionism: Perspective and Method; University of California Press: Berkeley, CA, USA; Los Angeles, CA, USA, 1986; ISBN 978-0520056763.

77. Fornäs, J. Cultural Theory and Late Modernity; Sage: London, UK, 1995; ISBN 978-0803989016.

78. Kellner, D. Media Spectacle; Routledge: London, UK, 2003; ISBN 978-0415268295.

79. Pihlström, S.; Kivistö, S. Sivistyksen Puolustus. Miksi Akateemista Elämää Tarvitaan? Gaudeamus: Helsinki, Finland, 2018; ISBN 9789524954655.

80. Míguez, N.O. Markets and the Bible. In Christianity, Consumerism and the Market; Irrázaval, D., Nadar, S., Ross, S.A., Eds.; SCM Press: London, UK, 2014; pp. 17-24, ISBN 9780334031307.

81. Johansson, F. Hyvän Tekemisen Markkinat; Gaudeamus: Helsinki, Finland, 2017; ISBN 978-952-495-437-2. 
82. Turner, G. Understanding Celebrity, 2nd ed.; Sage: Thousand Oaks, CA, USA, 2013; ISBN 978-1-4462-5321-2.

83. Couldry, N.; Hepp, A. The Mediated Construction of Reality; Polity Press: Cambridge, UK, 2017; ISBN 978-0745681313.

84. Taylor, B. Dark Green Religion: Nature Spirituality and the Planetary Future; University of California Press: Berkeley, CA, USA, 2009; ISBN 978-0520261006.

85. Ahlbäck, T. (Ed.) Post-Secular Religious Practices; Donner Institute for Research in Religious and Cultural History: Turku, Finland, 2012; ISBN 978-952-12-2700-4.

86. Wickström, L. Contemporary Environmentalism as a Current of Spiritual Post-Secular Practice. In Post-Secular Religious Practices; Ahlbäck, T., Ed.; Donner Institute for Research in Religious and Cultural History: Turku, Finland, 2012; pp. 419-432, ISBN 978-952-12-2700-4.

87. Durkheim, É. The Elementary Forms of Religious Life; Free Press: New York, NY, USA, 1995; ISBN 0-02-907937-3.

88. Vygotzky, L. Thought and Language; The MIT Press: Cambridge, MA, USA, 1986; ISBN 0262720108.

89. Muñiz, A.M., Jr.; O’Guinn, T.C. Brand Community. J. Consum. Res. 2001, 27, 412-431. [CrossRef]

90. McAlexander, J.H.; Schouten, J.W.; Koenig, H.J. Building Brand Community. J. Mark. 2002, 66, 38-54. [CrossRef]

91. Hollenbeck, C.R.; Peters, C.; Zinkhan, G.M. Gift Giving: A Community Paradigm. Psychol. Mark. 2006, 23, 573-595. [CrossRef]

92. Hollenbeck, C.R.; Zinkhan, G.M. Consumer activism on the internet: The role of anti-brand communities. Adv. Consum. Res. 2006, 33, 479-485.

93. The Vegan Society. Available online: www.vegansociety.com (accessed on 29 April 2018).

94. The Vegan Society: Definition of Veganism. Available online: https:/ /www.vegansociety.com/go-vegan/ definition-veganism (accessed on 29 April 2018).

95. Sheffield, T. The Religious Dimensions of Advertising; Palgrave MacMillan: Basingstoke, UK, 2006; ISBN 9780230601406.

96. Deuze, M. Media Life; Polity Press: Cambridge, UK, 2012; ISBN 978-0745650005.

97. Sumter, S.R.; Vandenbosch, L.; Ligtenberg, L. Love Me Tinder: Untangling Emerging Adults' Motivations for Using the Dating Application Tinder. Telemat. Inform. 2017, 34, 67-78. [CrossRef]

98. David, G.; Cambre, C. Screened Intimacies: Tinder and the Swipe Logic. Soc. Media+ Soc. 2016, 2. [CrossRef]

99. Lundahl, O. From a Moral Consumption Ethos to an Apolitical Consumption Trend. The Role of Media and Celebrities in Structuring the Rise of Veganism. Ph.D. Thesis, University of Vaasa, Vaasa, Finland, 8 September 2017.

100. De Backer, C.; Nelissen, M.; Vyncke, P.; Braeckman, J.; McAndrew, F. Celebrities: From Teachers to Friends. A Test of Two Hypotheses on the Adaptiveness of Celebrity Gossip. Hum. Nat. 2007, 18, 334-354. [CrossRef] [PubMed]

101. Anderson, B. Imagined Communities: Reflections on the Origin and Spread of Nationalism; Verso: London, UK, 2006; ISBN 978-1-84467-484-8.

102. Kasser, T.; Kanner, A.D. (Eds.) Psychology and Consumer Culture: The Struggle for a Good Life in a Materialistic World; American Psychological Association: Washington, DC, USA, 2002; ISBN 978-1-59147-046-5.

103. Foxall, G.; Goldsmith, R.E.; Brown, S. Consumer Psychology for Marketing, 2nd ed.; Thomson: London, UK, 1998; ISBN 978-1861523716.

104. Schmitt, B. The Consumer Psychology of Brands. J. Consum. Psychol. 2012, 22, 7-17. [CrossRef]

105. Norgaard, R.B.; Goddard, J.J.; Sager, J. Economy. In Routledge Handbook of Religion and Ecology; Jenkins, W., Tucker, M.E., Grim, J., Eds.; Routledge: New York, NY, USA, 2017; pp. 402-411, ISBN 9781315764788.106.

106. Zanesco, B. Smart Girls Screw up Too: The No-Nonsense Guide to Creating the Life You Want; John Wiley \& Sons: Milton, Australia, 2018; ISBN 978-0730345435.

107. Bauman, Z. Liquid Modernity; Polity Press: Cambridge, UK, 2000; ISBN 978-0745624105.

108. Valerio, R. Just Living. Faith and Community in an Age of Consumerism; Hodder \& Stoughton: London, UK, 2016; ISBN 9781473613331.

109. Schouten, J.W.; McAlexander, J.H.; Koenig, H.F. Transcendent customer experience and brand community. J. Acad. Mark. Sci. 2007, 35, 357-368. [CrossRef]

(C) 2018 by the authors. Licensee MDPI, Basel, Switzerland. This article is an open access article distributed under the terms and conditions of the Creative Commons Attribution (CC BY) license (http:// creativecommons.org/licenses/by/4.0/). 